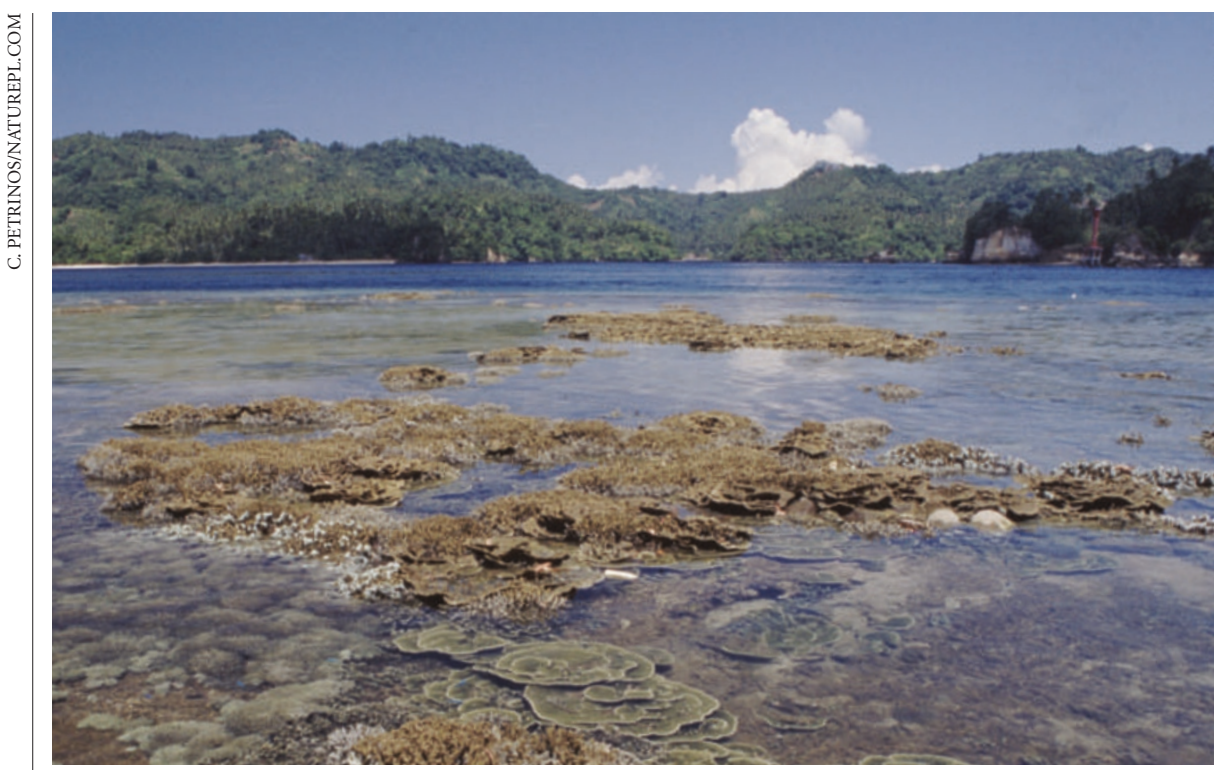

Seismic sensitivity: coral retains a record of changes in sea level, and hence of past earthquakes.

\title{
Indian Ocean fault line poses threat of further earthquakes
}

\section{Emma Marris}

Just weeks after the earthquake that triggered the devastating tsunami in the Indian Ocean, seismologists are turning their attention to nearby sections of the fault line that are also prone to rupture.

Researchers say that there could be further earthquakes both to the north and south of the event that occurred on 26 December, perhaps within decades, and that they might even be powerful enough to cause another tsunami.

The location of the epicentre of last month's earthquake is clear, but seismologists are uncertain where the northern edge of the rupture ended, says Kenji Satake, who studies tsunamis at the National Institute of Advanced Industrial Science and Technology in Tsukuba, Japan.

Some of the northern sections of the fault line may still be under enough strain to cause another earthquake of similar magnitude, says Satake, who hopes to go to the Andaman and Nicobar Islands in February to look for uplift of the land: no uplift would indicate that the fault has not yet ruptured in that area.

Likewise, some sections of the fault line south of the epicentre, which have definitely not yet ruptured, seem to be due for an earthquake.

Kerry Sieh, a geologist at the California Institute of Technology in Pasadena, has been investigating this area for years. He has a network of six instruments on a number of small islands off the coast of Sumatra, the exact locations of which are recorded by global positioning satellites. These reveal that the islands are currently sinking by as much as a centimetre a year, as the continental plate on which they sit is slowly dragged down into the subduction zone by the oceanic plate. When these plates slip during an earthquake, the islands spring back up again as the pressure on the continental plate is released.

Sieh has been investigating historical records of earthquakes in the area by looking at the coral, which retains a record of the lowtide mark - coral can only live under water, so it dies off if the low-tide mark recedes, or grows if the low-tide mark rises. Sieh has used this to estimate changes in elevation to within a couple of centimetres over the past 50 to 100 years, and to look for larger rises associated with past earthquakes.

Sieh says that earthquakes in the region happen about once every 230 years. "We think we are getting close to the next one," he says. The last such event on the Mentawai islands was 145 to 170 years ago, for example. Energy from last month's earthquake will have placed extra strain on the fault, which is likely to hasten the next rupture.

As the Sumatra study progresses, Sieh and his team have been teaching the islanders about earthquake risks. "We have been trying to educate the villagers with posters and brochures, telling them how to build their structures," he says. "I cross my fingers that the people we started to educate took our advice and clambered up the hill when the tsunami hit."

Additional reporting by David Cyranoski.

For more on the tsunami visit:

www.nature.com/news/infocus/tsunami.html
Pasteur board quits in bid to resolve crisis at troubled institute

Declan Butler, Paris

The board of directors of the Pasteur Institute in Paris has resigned en masse, in the latest twist in a bitter dispute between staff and management over the running of the institute.

The dispute centres on plans to relocate part of the prestigious research centre to a commercial zone on the city outskirts (see Nature 432,788 ; 2004) but it also involves what critics see as the brash management style of the institute's director-general, Philippe Kourilsky.

The institute's board has 16 elected members and four appointed by the government. The elected members are chosen every six years by its assembly a sort of parliament of some $\mathbf{1 0 0}$ members.

Several board members have said they are unhappy with the direction that the biomedical research institute is taking. And the board has come under fire from the assembly and scientists for failing to intervene.

Last June, the assembly refused to approve the Pasteur's annual report prepared by the board, in protest at a looming funding crisis there (see Nature 430, 283; 2004), and in December hundreds of scientists picketed a board meeting, calling for the resignation of Kourilsky and board chairman Michel Bon.

In these circumstances, says Nadine Peyrolo, a Pasteur spokeswoman, the board felt it no longer had the legitimacy needed to govern the institute. A new board that has the confidence of staff will have renewed legitimacy, suggests Sophie Chevallon, a spokeswoman for the science ministry, which has a permanent seat on the board. "We hope this will help to find a way out of the crisis," she says.

An extraordinary meeting of the assembly has been set for 15 March to elect a new board. One of its most urgent tasks will be to re-elect Kourilsky for another six-year term - or replace him.

Shortly after the board resigned on 12 January, the Pasteur's management e-mailed staff to announce that Kourilsky intends to send them all a letter detailing his actions and informing them of his "desire to open up a dialogue" with them.

But in a telling sign of the climate on campus, an internal memo from the institute's management says the dialogue will take the form of an Internet chat between staff and Kourilsky on 21 January, in which staff will have "perfect anonymity" so that "everyone can express themselves freely". 